\title{
ANALISIS TINGKAT KEPUASAN DAN TINGKAT KEPENTINGAN PENERAPAN SISTEM INFORMASI UNIVERSITAS MUHAMMADIYAH MALANG
}

\author{
Rellanti Diana Kristy ${ }^{1}$, Wahyu Andhyka Kusuma ${ }^{2}$ \\ Teknik Informatika, Fakultas Teknik \\ Universitas Muhammadiyah Malang, Malang, Indonesia \\ e-mail : ${ }^{1}$ rellantidiana@yahoo.com, ${ }^{2}$ kusuma.wahyu.a@gmail.com \\ Diterima: 18 April 2018. Disetujui : 15 Juni 2018. Dipublikasikan : 29 Juni 2018 \\ (C)2018 -TESJ Fakultas Teknik Universitas Maarif Hasyim Latif. Ini adalah artikel dengan \\ akses terbuka di bawah lisensi CC BY 4.0 (https://creativecommons.org/licenses/by/4.0/)

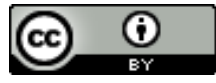

\section{ABSTRAK}

Untuk mengetahui apakah sistem informasi Universitas Muhammadiyah Malang berjalan sebagaimana mestinya, maka diperlukan proses evaluasi terhadap kinerja dari sistem informasi tersebut. Evaluasi dapat dilakukan dengan dengan berbagai cara sesuai dengan tujuan dari evaluasi tersebut. Evaluasi yang dilakukan terhadap sistem informasi Universitas Muhammadiyah Malang dengan menggunakan PIECES Framework. Analisis dilakukan dengan menggunakan 6 fokus analisis yaitu performance, information and data, economy, control and security, efficiency, dan service. Tujuan penelitian ini adalah untuk mengetahui tingkat kepuasan dan tingkat kepentingan sistem informasi Universitas Muhammadiyah Malang, mengetahui kelemahan dan kekuatan dan menganalisis komponen apa saja yang perlu ditingkatkan kualitas pelayanannya. Data didapatkan dari penyebaran kuesioner terhadap 40 pengguna sistem informasi Universitas Muhammadiyah Malang. Hasil penelitian ini diketahui bahwa pengukuran rata-rata tingkat kepuasan berada pada 3,6 yang berarti sistem informasi Universitas Muhammadiyah Malang telah memberikan kepuasan kepada pengguna, sedangkan untuk nilai pengukuran rata-rata tingkat kepentingan 3,4 yang berarti sistem informasi Universitas Muhammadiyah Malang dianggap penting oleh pengguna.

Kata kunci: framework pieces, importance performance analysis, ipa, sistem informasi, tingkat kepuasan, tingkat kepentingan

\section{PENDAHULUAN}

Sistem Informasi Universitas Muhammadiyah Malang (UMM) merupakan sebuah website yang dirancang secara dinamis. Portal wesite atau situs web adalah situs yang dapat diakses dan dilihat oleh pengguna internet di seluruh dunia. Sistem informasi ini terhubung atau terintegrasi dengan semua unit kerja UMM. Website resmi UMM sudah dikembangkan sejak tahun 1995 dan mulai diarsipkan sejak tahun 1998. Pengembangan masih terus dilakukan sampai saat ini. Pada tahun 2013 website UMM (umm.ac.id) mendapatkan ranking 1.440 webomatric untuk tingkat dunia dan tingkat 18 untuk website di tingkat Indonesia. Seiring dengan pengembangan yang terus dilakukan, website UMM sudah dapat menerjemahkan tiga bahasa yaitu Inggris, Indonesia dan Arab. Pada tahun 2011 bahasa Inggris ditetapkan sebagai default. Penggunaan tiga bahasa pada website UMM berhasil meningkatkan jumlah visitor ke website UMM. Secara khusus, fitur yang ada menentukan evaluasi kualitas dan layanannya. Sudut pandang pengguna berubah sesuai dengan karakteristik produk itu sendiri.

Untuk mengetahui apakah Sistem Informasi UMM berjalan dengan semestinya, perlu dilakukan evaluasi terhadap kinerja sistem informasi tersebut. Evaluasi dapat dilakukan dengan mengukur tingkat kepuasan dan tingkat kepentingan sesuai dengan tujuan dari evaluasi yang dilakukan. Evaluasi ini dilakukan untuk mengetahui kelebihan dan kekurangan Sistem Informasi UMM sehingga selanjutnya dapat dilakukan perbaikan. Tingkat kepuasan pengguan adalah terpenuhinya keinginan dan kebutuhan pengguna selama menggunakan sistem informasi tersebut. Sedangkan tingkat kepentingan pengguna adalah kondisi dimana sebuah sistem informasi tersebut dianggap penting untuk membantu proses dalam memanfaat sistem informasi dalam kegiatan yang dilakukan.

Analisis tingkat kepuasan dan tingkat kepentingan Sistem Informasi UMM dilakukan untuk mengetahui kelemahan sistem informasi tersebut. Metode yang digunakan adalah metode analisis PIECES framework. Metode ini merupakan 
sebuah metode yang digunakan untuk mengklasifikasikan suatu problem, opportunities, dan directives yang terdapat pada bagian scope definition, analisis dan perancangan sistem. Analisis yang dilakukan dengan menggunakan 6 variabel yaitu performance, information and data, economy, control and security, efficiency, dan service. Analisis yang dilakukan untuk mengetahui bagaimana kulitas sebuah sistem tersebut digunakan sebuah metode, yaitu Importance Performance Analysis (IPA). penambahan model IPA karena setiap organisasi dibatasi oleh keterbatasan sumber daya yang dimiliki. Dengan demikian, harus diputuskan bagaimana sumber daya yang terbatas itu yang terbaik diterapkan untuk mencapai tingkat kepuasan pengguna tertinggi. Importance Performance Analysis (IPA) dianggap sebagai metode yang tepat dalam memeriksa kepuasan pelanggan dan strategi manajemen. Asumsi yang mendasarinya teknik IPA adalah tingkat kepuasan pelanggan dengan atribut terutama berasal dari harapan mereka dan penilaian kinerja produk atau layanan. Model IPA diyakini sebagai metode yang efektif untuk mengatur prioritas. Ini adalah ruang status dua dimensi dimana sumbu vertikal menggambarkan pentingnya pemilihan dimensi, sedangkan horizontal menggambarkan seberapa baik penyedia layanan sedang melakukan layanan.

Hasil dari penelitian ini adalah sebuah dokumen kelemahan sistem informasi yang dapat dijadikan rekomendasi perbaikan. Rekomendasi perbaikan dapat digunakan pada pengembangan selanjutnya yang akan dilakukan.

\section{METODE PENELITIAN}

Jenis penelitian ini menggunkan penelitian deskriptif kuantitatif yang bertujuan untuk menggambarkan dan meringkas dari berbagai situasi dan kondisi yang muncul dimasyarakat yang menjadi objek penelitian, untuk melakukan penilaian berdasarkan persepsi responden dalam hal ini adalah Sistem Informasi UMM.

\section{Instrument Penelitian}

Instrument penelitian yang digunakan menggunakan kuesioner karena mudah untuk diimplementasi dan juga dapat dipercaya untuk mengukur pangalaman pengguna dalam hal ini adalah kepentingan dan kepuasan. Kuesioner yang digunakan merupakan adaptasi dari penelitian sebelumnya. Kuesioner terdiri dari 6 variabel yaitu performance, information and data, economy, control and security, efficiency, dan service. Variable tersebut termasuk kedalam variable kualitatif dan kuantitatif karena menyatakan kualitas tertentu dari suatu yang diamati di dalam penelitian. Skala perhitungan yang digunakan adalah skala likert. Skala likert digunakan untuk mengukur seberapa setuju responden terhadap pernyataan-pernyataan yang terdapat pada kuesioner. Penelitian ini menggunakan skala likert 5.

\section{Populasi}

Populasi merupakan keseluruhan dari objek penelitian yang dapat diteliti. Objek penelitian ini adalah Sistem Informasi Universitas Muhammadiyah Malang. Sumber data didapatkan dari pengguna Sistem Informasi Universitas Muhammadiyah Malang.

2. Sampel

Sampel diambil menggunakan purposive sampling yaitu teknik pengambilan sampel dengan pertimbangan tertentu. Artinya setiap subjek yang diambil dari populasi dipilih dengan sengaja berdasarkan tujuan dan pertimbangan tertentu. Jumlah peserta atau sampel yang diperlukan untuk mengevaluasi untuk mendapatkan hasil yang cukup stabil bahwa 2030 orang. Sampel yang diambil dalam penelitian ini sebanyak 40 orang yang dipilih dari pengguna sistem informasi Universitas Muhammadiyah Malang dengan status mahasiswa Universitas Muhammadiyah Malang

\section{PIECES Framework}

PIECES framework adalah sebuah metode yang digunakan untuk mengklasifikasikan suatu problem, opportunities, dan directives yang terdapat pada bagian scope definition, analisis dan perancangan sistem.

Dengan menggunakan metode ini dapat dihasilkan hal-hal baru yang dapat dijadikan pertimbangan dalam pengembangan sistem. Dalam PIECES terdapat enam variabel yang digunakan untuk menganalisis sistem informasi, yaitu:

\section{Performance (Keandalan)}

Variable ini digunakan untuk mengetahui kinerja sebuah sistem, apakah berjalan dengan baik atau tidak. Kinerja ini dapat diukur dari jumlah temuan data yang dihasilkan dan seberapa cepat suatu data dapat ditemukan.

2. Information and Data (Data dan Informasi)

Dalam sebuah temuan data pasti akan dihasilkan sebuah informasi yang akan ditampilkan,variable ini digunakan utnuk menganalisis seberapa banyak dan seberapa jelas informasi yang akan dihasilkan untuk satu pencarian.

3. Economics (Nilai Ekonomis)

Variable ini digunakan untuk melakukan analisis pada sistem, untuk mengetahui apakah suatu sistem tersebut tepat diterapkan pada suatu lembaga informasi dilihat dari segi finansial dan biaya yang dikeluarkan. Hal ini sangat penting 
karena suatu sistem juga dipengaruhi oleh besarnya biaya yang dikeluarkan.

4. Control and Security (Pengendalian dan Pengamanan)

Dalam suatu sistem perlu diadakan sebuah control atau pengawasan agar sistem itu berjalan dengan baik. Analisis ini digunakan untuk mengetahui sejauh mana pengawasan dan kontrol yang dilakukan agar sistem tersebut berjalan dengan baik.

5. Efficiency (Efisiensi)

Efisiensi dan efektivitas sebuah sistem perlu dipertanyakan dalam kinerja dan alasan mengapa sistem itu dibuat. Sebuah sistem harus bisa secara efisien menjawab dan membantu suatu permasalahan khususnya dalam hal otomasi. Analisis ini dilakukan untuk mengetahui apakah suatu sistem itu efisien atau tidak, dengan input yang sedikit bisa menghasilkan sebuah output yang memuaskan.

6. Service (Pelayanan)

Dalam hal pemanfaat suatu sistem, sebuah pelayanan masih menjadi suatu hal yang penting dan perlu diperhatikan. Suatu sistem yang diterapkan akan berjalan dengan baik dan seimbang bila diimbangi dengan pelayanan yang baik juga. Analisis ini digunakan untuk mengetahui bagaimana pelayanan yang dilakukan dan mengetahui permasalahan permasalahan yang ada terkait tentang pelayanan.

Tabel 1. Domain Pieces Framework

\begin{tabular}{llc}
\hline No & Variabel & Jumlah pernyataan \\
\hline 1 & Performance & 6 \\
2 & Information and Data & 10 \\
3 & Economics & 3 \\
4 & Control and Security & 7 \\
5 & Efficiency & 3 \\
6 & Service & 7 \\
\hline
\end{tabular}

Tabel 2. Skala Likert Tingkat Kepuasan

\begin{tabular}{llc}
\hline Pilihan Jawaban & Singkatan & Skor \\
\hline Sangat Setuju & SS & 5 \\
Setuju & S & 4 \\
Ragu-Ragu & RG & 3 \\
Tidak Setuju & TS & 2 \\
Sangat Tidak Setuju & STS & 1 \\
\hline
\end{tabular}

Tabel 3. Skala Likert Tingkat Kepentingan

\begin{tabular}{llc}
\hline Pilihan Jawaban & Singkatan & Skor \\
\hline Sangat Penting & SP & 5 \\
Penting & P & 4 \\
Ragu-Ragu & RG & 3 \\
Tidak Penting & TP & 2 \\
Sangat Tidak Penting & STP & 1 \\
\hline
\end{tabular}

Tabel 4. Skala Likert Tingkat Kepentingan

\begin{tabular}{lll}
\hline Range Nilai & Predikat Kepuasan & Predikat Kepentingan \\
\hline $1-1.79$ & Sangat Setuju & Sangat Penting \\
$1.8-2.59$ & Setuju & Penting \\
$2.6-3.39$ & Ragu-Ragu & Ragu-Ragu \\
$3.4-4.91$ & Tidak Setuju & Tidak Penting \\
$4.2-5$ & Sangat Tidak Setuju & Sangat Tidak Penting \\
\hline
\end{tabular}

\section{Pengumpulan Data}

Metode pengumpulan data adalah teknik atau cara yang dilakukan oleh peneliti untuk mengumpulkan data yang dilakukan untuk memperoleh informasi yang dibutuhkan dalam rangka mencapai tujuan penelitian.

Observasi dilakukan dengan cara menyebarkan daftar pernyataan kepada responden yaitu pengguna Sistem Informasi UMM berdasarkan model PIECES framework, kemudian data akan diolah dengan menggunakan aplikasi Microsoft Excel. Kuesioner terdiri dari 36 pernyataan, yang disusun berdasarkan 6 domain PIECES.

\section{Metode Analisis Data}

Dalam melakukan analisis data yang didapatkan dari kuesioner menggunakan metode likert, dengan persamaan (1).

$$
R K=\frac{J S K}{J K}
$$

dengan :

$R K$ : rata-rata kepuasan/kepentingan

$J S K$ : jumlah skor kuesioner

$J K$ : jumlah kuesioner

Tabel 5. Tabulasi Tingkat Kepuasan Pengguna

\begin{tabular}{lll}
\hline Domain & Rata-rata & Predikat \\
\hline Performance & 3,54 & PUAS \\
Information and Data & 3,74 & PUAS \\
Economics & 3,66 & PUAS \\
Control and Security & 3,6 & PUAS \\
Efficiency & 3,94 & PUAS \\
Service & 3,28 & PUAS \\
\hline
\end{tabular}

Tabel 6. Tabulasi Kuesioner Tingkat Kepentingan

\begin{tabular}{lcl}
\multicolumn{3}{c}{ Pengguna } \\
\hline Domain & Rata-rata & Predikat \\
\hline Performance & 2,46 & TIDAK PENTING \\
Information and Data & 3,58 & PENTING \\
Economics & 3,72 & PENTUNG \\
Control and Security & 3,72 & PENTING \\
Efficiency & 4,09 & PENTING \\
Service & 3,88 & PENTING \\
\hline
\end{tabular}

Tabel 7. Nilai Rata-rata Tingkat Kepuasan dan Tingkat Kepentingan

\begin{tabular}{lccc}
\hline \multicolumn{1}{c}{ Domain } & Butir No. & $\begin{array}{c}\text { Rata-rata } \\
(x)\end{array}$ & $\begin{array}{c}\text { Rata-rata } \\
(y)\end{array}$ \\
\hline Performance & $1-6$ & 3,54 & 2,46 \\
Information and Data & $7-16$ & 3,74 & 3,58 \\
Economics & $17-19$ & 3,66 & 3,72 \\
Control and Security & $20-26$ & 3,6 & 3,72 \\
Efficiency & $27-29$ & 3,94 & 4,09 \\
Service & $30-36$ & 3,28 & 3,88 \\
\hline
\end{tabular}

\section{HASIL DAN PEMBAHASAN}

PIECES framework merupakan sebuah metode yang digunakan untuk mengklasifikasikan suatu problem, opportunities, dan directives yang terdapat pada bagian scope definition, analisis dan 
perancangan sistem. Analisis yang dilakukan dengan menggunakan 6 variabel yaitu performance, information and data, economy, control and security, efficiency, dan service. Mengetahui tingkat kesesuaian yang merupakan hasil perbandingan skor tingkat kepuasan dengan tingkat kepentingan.

\section{Instrument Penelitian}

Instrumen penelitian bisa dilihat pada Tabel 8 Daftar Pernyataan PIECES Framework

\section{Perhitungan dan Analisis Data}

Dengan persamaan rata-rata kepuasan dan kepentingan untuk menentukan rata-rata tingkat kepentingan dan kepuasan pengguna terhadap penggunaan dan penerapan sistem informasi DJP online diperoleh rata-rata tingkat kepuasan berdasarkan domain yang terdapat pada PIECES framework adalah sebagai berikut:

1. Tingkat Kepuasan

Berdasarkan hasil perhitungan jumlah rata-rata tingkat kepuasan dengan menggunakan PIECES framework, maka didapatkan hasil seperti pada Tabel 5. Pada tabel tersebut menunjukan bahwa pengguna sistem informasi Universitas Muhammadiyah Malang berdasarkan balance scorecard dan PIECES framework sudah merasa PUAS dalam penggunaan sistem informasi Universitas Muhammadiyah Malang.

2. Tingkat Kepentingan

Berdasarkan hasil perhitungan jumlah rata-rata tingkat kepentingan dengan menggunakan PIECES framework, maka didapatkan hasil seperti pada Tabel 6. Pada tabel tersebut menunjukan bahwa pengguna sistem informasi Universitas Muhammadiyah Malang berdasarkan balance scorecard dan PIECES framework sudah dianggap penting hanya saja pada domain performance masih belum dianggap penting oleh pengguna sistem informasi Universitas Muhammadiyah Malang.

\section{Analisis Tingkat Kepentingan dan Kepuasan Pengguna Sistem Informasi Universitas Muhammadiyah Malang}

Dari pengukuran tingkat kepuasan dan tingkat kepentingan yang diambil dari 40 responden pengguna sistem informasi Universitas Muhammadiyah Malang, dihasilkan suatu perhitungan mengenai tingkat kesesuaian antara tingkat kepuasan dan tingkat kepentingan dan penerapan sistem informasi Universitas Muhammadiyah Malang. Metode yang digunakan adalah deskriptif kuantitatif dengan menggunakan importance-performance analysis. Dalam penggunaan metode ini diperlukan pengukuran tingkat kesusaian untuk mengetahui tingkat kepuasan pengguna terhadap sistem informasi
Universitas Muhammadiyah Malang. Rumus yang digunakan pada persamaan (2).

$$
T k_{i}=\frac{x_{i}}{y_{i}} \times 100 \%
$$

dengan :

$T k_{i}$ : tingkat kesesuaian responden

$x_{i}$ : skor rata-rata tingkat kepuasan

$y_{i}$ : skor rata-rata tingkat kepentingan

Dari Tabel 7 nilai rata-rata tingkat kepuasan dan kepentingan di atas, diperoleh tingkat kesesuaian dari kerangka PIECES. Tingkat kesesuaian domain performance sistem informasi Universitas Muhammadiyah Malang sebesar 143,9 \%., tingkat kesesuaian domain information and data sistem informasi Universitas Muhammadiyah Malang sebesar 144,96\% yang berarti presepsi pengguna terhadap kepentingan lebih besar dibandingkan kepuasan, dan tingkat kesesuaian domain economics sistem informasi Universitas Muhammadiyah Malang sebesar 98,38\%, tingkat kesesuaian domain control and security sistem informasi Universitas Muhammadiyah Malang sebesar 96,77\%, tingkat kesesuaian domain efficiency sistem informasi Universitas Muhammadiyah Malang sebesar 97,04\%, tingkat kesesuaian domain service sistem informasi Universitas Muhammadiyah Malang sebesar $84,53 \%$ yang berarti presepsi pengguna terhadap kepuasan lebih besar dibandingkan dengan kepentingan.

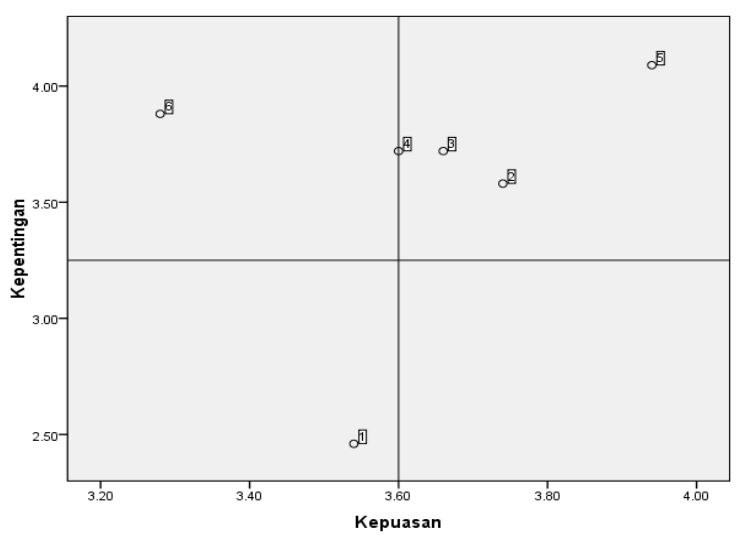

Gambar 1 Diagram Kartesius tingkat kepuasan dan tingkat kepentingan Sistem Informasi Universitas Muhammadiyah Malang

Interprestasi dari diagram kartesius pada gambar 1 dapat dijelaskan sebagai berikut:

a. Kuadran A

Kuadran ini menunjukkan faktor yang mempengaruhi kepuasan pengguna dan kepentingan penerapan sistem informasi Universitas Muhammadiyah Malang yang perlu diprioritasikan. Komponen yang berada pada kuadran ini adalah service yang menggambarkan bahwa kedua komponen dalam penerapannya 
dianggap penting namun pengguna belum merasa puas dengan kedua komponen tersebut.

b. Kuadran B

Kuadran ini menunjukkan faktor yang mempengaruhi kepuasan pengguna dan kepentingan penerapan sistem informasi Universitas Muhammadiyah Malang yang dikategorikan sudah baik dan harus dipertahankan. Komponen yang berada pada kuadran ini adalah information and Data, Economics, control and security, effocoency yang menggambarkan bahwa penerapan sistem informasi Universitas Muhammadiyah Malang sudah dapat meningkatkan efisiensi dan efektivitas dalam penggunaan sistem informasi, pengguna juga sudah merasakan kepuasan terhadap sistem informasi Universitas Muhammadiyah Malang.

c. Kuadran C

Kuadran ini menunjukkan faktor yang mempengaruhi kepuasan pengguna dan kepentingan penerapan sistem informasi Universitas Muhammadiyah Malang yang dikategorikan prioritas rendah. Komponen yang berada pada kuadran ini adalah performance yang menggambarkan bahwa dalam penerapan sistem informasi Universitas Muhammadiyah Malang nilai ekonomis dan layanan tidak terlalu penting, pengguna belum merasakan kepuasan terkait nilai ekonomis dan layanan dari sistem informasi Universitas Muhammadiyah Malang.

d. Kuadran D

Kuadran ini menunjukkan faktor yang mempengaruhi kepuasan pengguna dan kepentingan penerapan sistem informasi Universitas Muhammadiyah Malang yang dikategorikan berlebihan. Tidak ada komponen yang berada didalam kuadran ini. Di dalam kuadran ini menggambarkan bahwa dalam penerapan sistem informasi Universitas Muhammadiyah Malang kinerja sistem dianggap penting, namun pengguna belum merasakan kepuasan terkait kinerja dari sistem informasi Universitas Muhammadiyah Malang.

\section{PENUTUP}

Berdasarkan hasil perhitungan yang dilakukan terhadap 40 data responden yang menggunakan Sistem Informasi Universitas Muhammadiyah Malang dan analisis tingkat kepuasan pengguna dalam menggunakan sistem informasi Universitas Muhammadiyah Malang dan analisis tingkat kepentingan penerapan sistem informasi Universitas Muhammadiyah Malang. Dapat disimpulkan menjadi beberapa bagian, berdasarkan analisis tingkat kepuasan dengan menggunakan metode analisis kerangka kerja
PIECES didapatkan nilai sebagai berikut : performance memperoleh skor 3,54, information and data memperoleh skor 3,7, economy memperoleh skor 3,66, control and security memperoleh skor 3,6, efficiency memperoleh skor 3,94 , dan service memperoleh skor 3,28. Sedangkan analisis tingkat kepentingan dengan menggunakan metode yang sama diperoleh hasil sebagai berikut: performance memperoleh skor 2,46, information and data memperoleh skor 2,58, economy memperoleh skor 3,72, control and security memperoleh skor 3,72, efficiency memperoleh skor 4,09 , dan service memperoleh skor 3,88. Hasil penelitian ini diketahui bahwa pengukuran ratarata tingkat kepuasan berada pada 3,7 yang berarti sistem informasi Universitas Muhammadiyah Malang telah memberikan kepuasan kepada pengguna, sedangkan untuk nilai pengukuran ratarata tingkat kepentingan 3,57 yang berarti sistem informasi Universitas Muhammadiyah Malang dianggap penting oleh pengguna. sistem informasi Universitas Muhammadiyah Malang sudah memiliki keunggulan akan tetapi masoh diperlukan adanya perbaikan dan pengembangan untuk menutupi kelemahan yang ditemukan.

\section{DAFTAR PUSTAKA}

Chen, Y.-L., \& Fan, K.-K. (2017). Exploratory study on corporate brand image and customer satisfaction on consumer purchase behavior: A case study of UNIQLO. In Applied System Innovation (ICASI), 2017 International Conference on (pp. 1190-1193). IEEE.

Cherapanukorn, V., \& Charoenkwan, P. (2017). Word Cloud of Online Hotel Reviews in Myanmar for Customer Satisfaction Analysis. In Advanced Applied Informatics (IIAI-AAI), 2017 6th IIAI International Congress on (pp. 447-452). IEEE.

Chiou, K.-C., Su, H.-H., Hsieh, Y.-Y., \& Tien, C.-H. (2017). Application of simultaneous importance-performance analysis to evaluate customer loyalty towards corporation: A case study of direct selling company S. In Awareness Science and Technology (iCAST), 2017 IEEE 8th International Conference on (pp. 210-214). IEEE.

Devy, N. P. I. R., Wibirama, S., \& Santosa, P. I. (2017). Evaluating user experience of english learning interface using User Experience Questionnaire and System Usability Scale. In Informatics and Computational Sciences (ICICoS), 2017 1st International Conference on (pp. 101-106). IEEE.

Hendarti, H., Christian, T. L., Permatasari, A., \& 
Nindito, H. (2017). Evaluation of web information system national land agency to improve user satisfaction. In Information Management and Technology (ICIMTech), 2017 International Conference on (pp. 3943). IEEE.

Keong, W. E. Y. (2017). Importance-Performance Analysis of e-Learning Technologies in Malaysian Higher Education. In Educational Technology (ISET), 2017 International Symposium on (pp. 24-28). IEEE.

Luo, C., Gao, H., Gao, C., \& Ma, W. (2015). An importance-performance analysis of Eservice quality. In Logistics, Informatics and Service Sciences (LISS), 2015 International Conference on (pp. 1-6). IEEE.

Rosalina, R., Utami, M. C., Kumaladewi, N., \& Putra, S. J. (2017). The psychometric and interpretative analyses for assessing the end-user computing satisfaction questionnaire. In Cyber and IT Service Management (CITSM), 2017 5th International Conference on (pp. 1-6). IEEE.
Supriyatna, A., \& Maria, V. (2018). Analisa Tingkat Kepuasan Pengguna dan Tingkat Kepentingan Penerapan Sistem Informasi DJP Online dengan Kerangka PIECES. Khazanah Informatika: Jurnal Ilmu Komputer Dan Informatika, 3(2), 88-94.

Tong, L., Hou, X., \& Li, X. (2016). Empirical study on customer satisfaction influencing factors of industry application products based on experiential level theory. China Communications, 13(11), 260-268.

Ulkhaq, M. M., Wijayanti, W. R., Kusumawati, A., Aulia, F. S., Wijayanti, R. S., \& Wiganingrum, R. (2017). Combining the eTransQual scale and importance-performance analysis to assess service quality of online shopping. In Industrial Engineering and Applications (ICIEA), 2017 4th International Conference on (pp. 146-150). IEEE. 


\section{LAMPIRAN}

Tabel 8. Daftar Pernyataan PIECES Framework

\begin{tabular}{|c|c|c|}
\hline No & Domain & Pernyataan \\
\hline \multirow[t]{6}{*}{1} & \multirow[t]{6}{*}{ Performance } & Sistem Informasi Universitas Muhammadiyah Malang Sangat Mudah Diakses Oleh Pengguna. \\
\hline & & $\begin{array}{l}\text { Sistem Informasi Universitas Muhammadiyah Malang Dapat Mengoperasikan Sejumlah Perintah Dalam } \\
\text { Waktu Yang Relatif Singkat, Tanpa Mengalami Hambatan. }\end{array}$ \\
\hline & & $\begin{array}{l}\text { Sistem Informasi Universitas Muhammadiyah Malang Dalam Merespon Suatu Perintah Pembatalan Maupun } \\
\text { Permintaan Terhadap Suatu Transaksi Dilakukan Dengan Cepat. }\end{array}$ \\
\hline & & $\begin{array}{l}\text { Jumlah Data Yang Dapat Diproses Sistem Informasi Universitas Muhammadiyah Malang Pada Satuan } \\
\text { Waktu Sudah Sesuai Dengan Yang Diharapkan. }\end{array}$ \\
\hline & & $\begin{array}{l}\text { Pada Saat Sistem Informasi Universitas Muhammadiyah Malang Digunakan Secara Bersamaan, Kinerja } \\
\text { Sistem Informasi Tetap Berjalan Stabil. }\end{array}$ \\
\hline & & $\begin{array}{l}\text { Total Waktu Yang Dibutuhkan Dalam Melakukan Pengolahan Data Hingga Menghasilkan Informasi Sudah } \\
\text { Dilakukan Dengan Cepat. }\end{array}$ \\
\hline \multirow[t]{10}{*}{2} & \multirow[t]{10}{*}{$\begin{array}{l}\text { Informasi dan } \\
\text { Data }\end{array}$} & $\begin{array}{l}\text { Data Yang Disimpan Oleh Sistem Informasi Universitas Muhammadiyah Malang Sudah Tersimpan Sesuai } \\
\text { Dengan Yang Dimasukkan Kedalam Sistem }\end{array}$ \\
\hline & & $\begin{array}{l}\text { Sistem Informasi Universitas Muhammadiyah Malang Tidak Dapat Menyimpan Data Yang Bukan } \\
\text { Seharusnya. }\end{array}$ \\
\hline & & $\begin{array}{l}\text { Data Yang Mengandung Kesalahan Atau Data Yang Tidak Benar Tidak Dapat Disimpan Oleh Sistem } \\
\text { Informasi Universitas Muhammadiyah Malang. }\end{array}$ \\
\hline & & $\begin{array}{l}\text { Sistem Informasi Universitas Muhammadiyah Malang Tidak Dapat Menyimpan Data Yang Sama Sehingga } \\
\text { Tidak Menimbulkan Duplikasi Atau Redudansi Data. }\end{array}$ \\
\hline & & Informasi Yang Dihasilkan Oleh Sistem Informasi Sudah Sesuai Dengan Yang Dibutuhkan. \\
\hline & & $\begin{array}{l}\text { Informasi Yang Dihasilkan Oleh Sistem Informasi Universitas Muhammadiyah Malang Tepat Pada } \\
\text { Waktunya. }\end{array}$ \\
\hline & & $\begin{array}{l}\text { Format Informasi Yang Dihasilkan Oleh Sistem Informasi Universitas Muhammadiyah Malang Bermanfaat } \\
\text { Dan Dapat Digunakan Sebagaimana Mestinya Oleh Pengguna. }\end{array}$ \\
\hline & & $\begin{array}{l}\text { Data Yang Diolah Oleh Sistem Informasi Universitas Muhammadiyah Malang Sudah Tersimpan Ke Dalam } \\
\text { Satu Media Penyimpanan. }\end{array}$ \\
\hline & & $\begin{array}{l}\text { Informasi Yang Disajikan Sistem Informasi Universitas Muhammadiyah Malang Mudah Untuk Dipelajari } \\
\text { Dan Dipahami. }\end{array}$ \\
\hline & & $\begin{array}{l}\text { Informasi Yang Dihasilkan Sistem Informasi Universitas Muhammadiyah Malang Dapat Diandalkan / } \\
\text { Dipercaya. }\end{array}$ \\
\hline \multirow[t]{3}{*}{3} & \multirow[t]{3}{*}{ Economics } & $\begin{array}{l}\text { Biaya Yang Dikeluarkan Untuk Mengakses Sistem Informasi Universitas Muhammadiyah Malang Cukup } \\
\text { Murah }\end{array}$ \\
\hline & & $\begin{array}{l}\text { Pada Saat Pembangunan Dan Penerapan Sistem Informasi Universitas Muhammadiyah Malang, Biaya Yang } \\
\text { Dikeluarkan Perusahaan Cukup Tinggi. }\end{array}$ \\
\hline & & $\begin{array}{l}\text { Ada Perubahan Yang Signifikan Dalam Hal Perkembangan Dan Pertumbuhan Dengan Adanya Sistem } \\
\text { Informasi Universitas Muhammadiyah Malang. }\end{array}$ \\
\hline \multirow[t]{7}{*}{4} & \multirow[t]{7}{*}{$\begin{array}{l}\text { Control And } \\
\text { Security }\end{array}$} & $\begin{array}{l}\text { Bentuk Pengamanan Yang Terdapat Pada Sistem Informasi Universitas Muhammadiyah Malang Sudah } \\
\text { Dapat Menjaga Data Atau Informasi Dari Berbagai Bentuk Kecurangan Atau Kejahatan }\end{array}$ \\
\hline & & Terdapat Pengontrolan Terpusat Terhadap Penggunaan Data. \\
\hline & & Sistem Pengamanan Pada Sistem Informasi Universitas Muhammadiyah Malang Sudah Baik \\
\hline & & $\begin{array}{l}\text { Manajemen Dalam Memberikan Otorisasi Dan Menentukan Pengendalian Akses Terhadap Penggunaan Dan } \\
\text { Pengoperasian Sistem Sudah Jelas }\end{array}$ \\
\hline & & Media Penyimpanan Aman Dari Perusakan Dan Kecelakaan. \\
\hline & & Media Penyimpanan Dapat Mengorganisasikan Data Dengan Baik. \\
\hline & & Dalam Pemeliharaan Sistem, Tidak Mengalami Kesulitan Baik Dari Segi Biaya Maupun Pelaksanaanya \\
\hline \multirow[t]{3}{*}{5} & \multirow[t]{3}{*}{ Efficiency } & Sistem Yang Digunakan Sekarang Lebih Meringankan Pengguna Baik Dari Segi Biaya Dan Waktu. \\
\hline & & $\begin{array}{l}\text { Penggunaan Sistem Informasi Universitas Muhammadiyah Malang Paling Berperan Dalam Hal Peningkatan } \\
\text { Informasi Universitas }\end{array}$ \\
\hline & & $\begin{array}{l}\text { Dalam Mengoperasikan Sistem Pada Kegiatan / Aktivitas Pengguna Sehari - Hari, Apakah Sistem Dapat } \\
\text { Menghasilkan Output Yang Sesuai Dengan Input User }\end{array}$ \\
\hline \multirow[t]{7}{*}{6} & \multirow[t]{7}{*}{ Service } & $\begin{array}{l}\text { Pihak Universitas Memberikan Bantuan Kepada Pengguna Dalam Penggunaan Sistem Informasi Universitas } \\
\text { Muhammadiyah Malang. }\end{array}$ \\
\hline & & Sistem Informasi Universitas Muhammadiyah Malang Mudah Dipelajari Dan Dipahami \\
\hline & & Sistem Informasi Universitas Muhammadiyah Malang Mudah Digunakan \\
\hline & & Sistem Informasi Universitas Muhammadiyah Malang Fleksibel Jika Digunakan Untuk Situasi Yang Baru \\
\hline & & Sistem Informasi Universitas Muhammadiyah Malang Dapat Dirubah Secara Fleksibel \\
\hline & & $\begin{array}{l}\text { Sistem Informasi Universitas Muhammadiyah Malang Terkoordinir Dan Terintegrasi Dengan Sistem Yang } \\
\text { Lain }\end{array}$ \\
\hline & & $\begin{array}{l}\text { Sistem Informasi Universitas Muhammadiyah Malang Dapat Memberikan Kepuasan Anda Sebagai } \\
\text { Pengguna Yang Membutuhkan Informasi }\end{array}$ \\
\hline
\end{tabular}


RD Kristy, dkk / Teknika : Engineering and Sains Journal, Vol. 2, No.1, Juni 2018, 17-24

Halaman ini sengaja dikosongkan 